\title{
Profiling of Up-Regulated Genes Response to Acute Hypo-Osmotic Stress in Hepatopancreas and Gill of the Pacific White Shrimps (Litopenaeus vannamei)
}

\author{
Hong-yu Liu ${ }^{1}$, Wu-wei Sun ${ }^{1}$, Xiao-hui Dong ${ }^{1}$, Shu-yan Chi ${ }^{1}$, Qi-hui Yang ${ }^{1}$, Yuan-you Li $^{2} \&$ Bei-ping Tan $^{1}$ \\ ${ }^{1}$ Laboratory of Aquatic Animal Nutrition and Feed, Fisheries College, Guangdong Ocean University, Zhanjiang, \\ China \\ ${ }^{2}$ Guangdong Provincial Key Laboratory of Marine Biotechnology, Shantou University, Shantou, China \\ Correspondence: Bei-ping Tan, Laboratory of Aquatic Animal Nutrition and Feed, Fisheries College, Guangdong \\ Ocean University, Zhanjiang, China. Tel: 86-759-238-3373. E-mail: bptan@126.com
}

Received: January 17, 2016 Accepted: January 31, 2016 Online Published: March 1, 2016

doi:10.5539/ijb.v8n2p43

URL: http://dx.doi.org/10.5539/ijb.v8n2p43

\begin{abstract}
Suppression subtractive hybridization (SSH) was applied to screen responsively up-regulation genes in hepatopancreas and gill of Litopenaeus vannamei induced by acute hypo-osmotic stress. In the hepatopancreas, 196 clones were randomly selected and sequenced. 131 non-redundant transcripts, corresponding to 41 genes, were found with elevated expressions. They were functionally clustered into eight biological processes which were protein synthesis and processing, carbohydrate metabolism and energy production, transport, cell growth, apoptosis, cytoskeletal component, cell defense and homeostasis, signal transduction, accounting for $26.2 \%$, $14.3 \%, 16.7 \%, 4.7 \%, 4.7 \%, 2.3 \%, 11.9 \%$ and $7.1 \%$, respectively. When confirmed by real time qRT-PCR, the gene expression levels of MnSOD, glutathione and glutamine synthetase showed significant increases (2.64-folds, 3.44 -folds and 2.16-folds, respectively) in hepatopancreas $(P<0.05)$. Totally 81 expressed sequence tags (ESTs) were obtained by random sequencing from the gill SSH cDNA library, and 52 unigenes, including 15 contigs and 37 singlets, after $\mathrm{CP} 3$ online matching were gained by clustering and assembling. The sequence alignment results revealed that 30 of them had significant homology to previously identified Genbank database sequences, while 22 unigenes did not match any sequence in the datebase and presumably represented unidentified cDNAs. Functionally, the unigenes were classified into six clusters, including ion channels and transport proteins (1); protein synthesis, translation and transcription factor (2); stress resistance and antioxidant factors (3); energy metabolism (4); signal receptor and transduction (5); cell fibrin and cytoskeletal proteins (6) with proportion of $23.3 \%, 20.0 \%, 20.0 \%, 16.7 \%, 10.0 \%$ and $10.0 \%$ respectively. Real time qRT-PCR confirmation revealed significant elevation of Arginine kinase, Carbonic anhydrase and NaK-ATPase- $\alpha$-subunit expressions (3.73-folds, 2.55 -folds and 5.83-folds, respectively) in the gill after acute low-osmotic stress $(\mathrm{P}<0.05)$. These results provided insight into critical physiology processes and pathways constituting the hypo-osmotic stress adaption program in hepatopancreas and gill of $L$. vannamei.
\end{abstract}

Keywords: Litopenaeus vannamei, hepatopancreas, gill, suppression subtractive hybridization (SSH), hypoosmotic stress

\section{Introduction}

Litopenaeus vannamei, has been cultured widely in many parts of the world, such as the US (Cuzon, Lawrence, Gaxiola, Rosas, \& Guillaume, 2004), Thailand (Thongsawad et al., 2007), China (Bi, Huang, Gu, Wang, \& Wang, 2008), Brazil (dos Santos Braz, Reis, Martins, de Sales, \& Meissner, 2009) and Indonesia. Recently, L. vannamei has been cultured in brackish water as well as freshwater because of its strong hypo-osmotic regulation. The tolerance of shrimps to acute salinity change dependent on their capability of osmotic physiological regulation, such as improvements of ion-transport enzymes activities (Jasmani, Jayasankar, Shinji, \& Wilder, 2010; L.-Q. Pan, Zhang, \& Liu, 2007), changes of free amino acids (FAAs) (Marangos, Brogren, Alliot, \& Ceccaldi, 1989; Silvia, Antonio, Francisco, \& Georgina, 2004), enhances of digestive enzymes activities (Li et al., 2008), increases of ammonia afflux rate (Pillai \& Diwan, 2002), elevations of oxygen consumption rate (Zhang, Zhang, Li, \& Gao, 2009) and optimization of genes transcript levels (Dong, Wang, Tian, Guo, \& Liu, 2011; Jayasundara, Spanings- 
Pierrot, \& Towle, 2004; Luquet, Weihrauch, Senek, \& Towle, 2005; Tiu, He, \& Chan, 2007). Most published studies on osmotic physiological adaption were focused on physiological apparent changes, while few of them dig into the molecular mechanism of the procedure.

In crustaceans, gill is the most important organ for respiration and osmoregulation (Pequeux, 1995). The osmoregulatory mechanism of $L$. vannamei in low salinity stress is accomplished through the coordination of a number of functional genes, usually accompanied by the modulation of mRNA expression levels of a series of osmoticrelated genes (Zhao, Pan, Ren, \& Hu, 2015). However, the classes and pathways of osmotic related genes are not yet fully revealed. The gill epithelial cells are the primary sites of shrimps for ion exchange with the environment. The ion channels and transmembrane proteins at the apical and basolateral membrane play important roles in the osmoregulation (Lovett et al., 2006). The hepatopancreas is regarded as one of the most important tissues involved in the innate immune defense of shrimp, and a digestive gland, which involved in digestion, absorption of nutrients, storage of reserves, synthesis and excretion of digestive enzymes (Franceschini-Vicentini et al., 2009). Shrimps produced more B cells in hepatopancreas tubules at salinity $3 \mathrm{ppt}$ than at salinity $17.0 \mathrm{ppt}$, which indicated that the high rate of synthesis and release of digestive and antioxidant enzymes accelerated the mobilization of nutrients in hepatopancreas tubules, by which more energy is supplied for omosregulation of shrimps at low salinity, and to adapt to environment stress (E. Li et al., 2008).

Suppression subtractive hybridization ( $\mathrm{SSH}$ ), an effective method to identify differently expressed genes (Diatchenko et al., 1996), was adopted to find involved genes and genes which have never been discovered. Employing SSH, Foil et al., (Fiol, Chan, \& Kültz, 2006) discovered 20 genes cluster together in six molecular processes that are rapidly activated in Tilapia gills upon salinity transfer; James et al., (James, Thampuran, Lalitha, Rajan, \& Joseph, 2010) identified 17 novel proteins which invovled in immunity in hepatopancreas of Fenneropenaeus; Pan et al., (D. Pan, He, Yang, Liu, \& Xu, 2005) found 8 novel genes related to virus-resistant in hepatopancreas of panaeid shrimps. Regarding osmoregulation of shrimps, Shekhar et al.,identified differentially expressed genes in response to salinity stress with suppression subtractive hybridization (SSH) through cDNA library constructed from gill and gut tissues of the giant tiger shrimps (Penaeus monodon) exposed to low (Shekhar, Kiruthika, \& Ponniah, 2013) and high (Shekhar, Kiruthika, Rajesh, \& Ponniah, 2014) salinity conditions. The resulted expressed sequence tags (EST) provided a partial description of the transcribed regions or activities of a genome in a tissue or an organism under specific experimental conditions. As a commercially important aquaculture spice, $L$. vannamei has been extensively studied. However, the up-regulation of its genes, particularly those involved in the physiological adaptation of the hepatopancreas to low saline condition, is rarely reported. This study aimed to identify the up-regulated genes induced by acute hypo-osmotic stress using SSH in the hepatopancreas and gill of $L$. vannamei and to provide a valuable insight into the immunity, osmoregulation and metabolic adaption mechanisms of $L$. vannamei under hypo-osmotic conditions.

\section{Method}

\subsection{Animals}

L. vannamei $(10.7 \pm 0.4 \mathrm{~g})$ were obtained from a farm in Zhanjiang, Guangdong, China, and then acclimatized for 2 weeks in a pool $\left(\right.$ at $\left.30^{\circ} \mathrm{C}\right)$ filled with aerated seawater $(30 \pm 2 \mathrm{ppt})$. The shrimps were fed on a commercial shrimp diet four times a day with $25 \%$ seawater exchanged every day.

\subsection{Hypo-Osmotic Stress and Samples Collection}

Shrimps with similar length and weight $(12.4 \pm 0.2 \mathrm{~g}$ ) were randomly distributed ( $\mathrm{n}=20 / \operatorname{tank})$ to $300 \mathrm{~L}$ experimental containers with either seawater (Control group) or low salinity dilute seawater (Treatment group). The salinity was gradually decreased from 30 to 4 ppt over a period of $12 \mathrm{~h}$ in the treatment group, while kept at $30 \mathrm{ppt}$ in the control group. Shrimps were sacrificed by removing their carapace from backside with a jerk 2 days after the salinity transfer. Hepatopancreata were quickly dissected out, flash frozen in liquid nitrogen and stored at $-80{ }^{\circ} \mathrm{C}$ until used for total RNA extraction. The experimental conditions were as follows: water temperature, $28.5 \pm 2{ }^{\circ} \mathrm{C}$; salinity, 30 or $4 \mathrm{ppt}$; dissolved oxygen, $10.30-10.50 \mathrm{mg} \mathrm{L}^{-1}$; $\mathrm{pH}, 7.8 \pm 0.5$.

\subsection{RNA Extraction and SMART cDNA Synthesis}

Total RNA was extracted from gills and hepatopancreata of L.vannamei using Unizol reagent (GENEray biotechnology, China) according to the manufacturer's protocol. Purity of RNA was confirmed by reading absorbance at 260 and $280 \mathrm{~nm}$. The ratio of background-free absorbance at 260/280 nm was always between 1.8 and 2.0. Reverse transcription of mRNAs from Control and Treatment were performed using SMART PCR cDNA Synthesis Kit (Clontech) according to the manufacturer's instructions. 


\subsection{Suppression Subtractive Hybridization}

The hepatopancreata and postgills of L.vannamei in hypo-osmotic stress (4 ppt) were used as the Tester with those from normal seawater (30 ppt) as the Driver respectively. SSH was performed to generate a SSH library using the PCR-Select cDNA Subtractive Kit (Clontech) according to the manufacturer's protocol. Briefly, SMART cDNAs from both group were digested with Rsa I at $37^{\circ} \mathrm{C}$ overnight to generate shorter blunt-ended double-strand cDNA and purified with Axyprep Clean Kit (AXYGEN). Aliquots of Rsa I-digested Tester cDNA were ligated with adaptor1 and adaptor2R (Table 1) respectively at 5'-end and hybridized at $68{ }^{\circ} \mathrm{C}$ for $8 \mathrm{~h}$ with the excess of driver cDNA after denaturation at $98{ }^{\circ} \mathrm{C}$ for $90 \mathrm{~s}$. After the first hybridization, the two samples were mixed together without denaturation and hybridized with the excess of fresh denatured driver cDNA for overnight incubation at $68^{\circ} \mathrm{C}$. The resulted mixture was diluted in $200 \mu \mathrm{L}$ dilution buffer and submitted to two rounds PCRs to enlarge the target cDNAs. Primer 1 (Table 1 ) against adaptor 1 and adaptor2R was used to selectively amplify differentially expressed cDNA in the primary PCR, followed the secondary PCR through a set of nested primers with the product of the first PCR as template. Finally, the SSH efficiency was evaluated by PCR with $\beta$-actin forward and reverse primers performed on tester (unsubtracted) and subtracted cDNA s for 18, 23, 28or 33 cycles.

\subsection{Cloning, Sequencing and Homology Analysis}

cDNAs were inserted directly into PED-T vector (Promega) and transformed into DH-5 $\alpha$ competent $E$. coli, followed by spreading onto LB agar plates containing AMP, X-Gal and IPTG. Blue clones were selectively sequenced. The sequences were clustered by CAP3 (http://pbil.univ-lyon1.fr/cap3.php), and then searched in the NCBI GenBank database for homology with Blastn and Blatstx (http://blast.ncbi.nlm.nih.gov/Blast.cgi). The significant matches presented E-values lower than $1 \mathrm{e}^{-6}$.

\subsection{Real Time qRT-PCR}

Real time qRT-PCR was used to confirm the differential expression of up-regulated genes in salinity-stress shrimps. Total RNA was extracted from hepatopancreas and gill. The first-strand cDNA was synthesized using the iScript ${ }^{\mathrm{TM}}$ cDNA synthesis kit (BIO-RAD). The reaction was conducted in a $20 \mu \mathrm{L}$ reaction volume consisting of RNA (100 ng), $4 \mu \mathrm{L}$ iScript reaction mix, $1 \mu \mathrm{L}$ iScript reverse transcriptase, and Nuclease-free $\mathrm{dH}_{2} \mathrm{O}$ at $25^{\circ} \mathrm{C}$ for 5 mins, then at $42{ }^{\circ} \mathrm{C}$ for 30 mins, and followed by 5 mins at $85{ }^{\circ} \mathrm{C}$.. The real time qPCR amplification was performed in a $10 \mu \mathrm{L}$ reaction volume consisting of $5 \mu \mathrm{L}$ SsoFast ${ }^{\mathrm{TM}}$ EvaGreen ${ }^{\circledR}$ supermix(BIO-RAD), $0.3 \mu \mathrm{L}$ forward primer (Table 1), $0.3 \mu \mathrm{L}$ reverse primer (Table 1), RNase/Dnase-free water and $1 \mu \mathrm{L}$ cDNA. The specific primers of ten up-regulated genes picked from the SSH libraries of hepatopancreas and gill (MnSOD, Ferritin, glutathione, destabilase I, glutamine synthetase, arginine kinase, Carbonic anhydrase, Serine protease, NaKATPaseasubunit, NaK-ATPase $\beta-2$ subunit) used for real time analysis are shown in Table 1 . The relative expression was normalized against $\beta$-actin using the comparative $\mathrm{Ct}$ method with the formula $2^{-\Delta \Delta \mathrm{Ct}}$ (where $\Delta \Delta \mathrm{Ct}$ $=\Delta \mathrm{Ct}$ sample $-\Delta \mathrm{Ct}$ reference) .

Table 1. Primers used for SSH library construction and gene specific real time PCR analysis of identified upregulated genes

\begin{tabular}{lll}
\hline Genes/ Names & Forward $\left(5^{\prime}\right.$ to 3' $^{\prime}$ ) & Reverse (5' to 3') \\
\hline Adaptor 1 & CATTACGACTCACTATAGGGCTCGAGCGGCCGCCCGGGCAGGT & GGCCCGTCCA \\
Adaptor 2R & CTAATACGACTCACTATAGGGCAGCGTGGTCGCGGCCGAGGT & GCCGGCTCCT \\
Primer 1 & CTAATACGACTCACTATAGGGC & \\
Nested PCR 1 & TCGAGCGGCCGCCCGCCCGGCAGG & \\
Nested PCR 2R & AGCGTGGTCGCGGCCGAGGT & \\
$\beta$-actin & CCTGTTCCAGCCTCAT & GTCCACGTCGCACTTCA \\
MnSOD & GCCAGCGTTGGAGTGAAAGG & TTGGTCGCCACGAGAAGTCA \\
Ferritin & CGTTTACCTTTCTATGGCTTAC & CACTTGTCCTCCAGATACTCA \\
glutathione & GGCACTGAGTTCGAGGAGA & TTCGTAGGTGACGGTAAAGA \\
destabilase I & CGCATCACCATTCTTCCTG & CGTAGTCCTCATTCATCCC \\
Glutamine synthetase & GGCATGGAGCAGGAGTA & CGCCGCAGTAGTAGGGT \\
arginine kinase & GCTGACGCTGCTGTTATTGAGA & GGTGGCGGCTTCAAGCTT \\
Carbonic anhydrase & CCCCACCTTGCTATGAATGC & TCCTGGGACAGCTGAATGG \\
Serine protease & TTCGTTGTTGCGCGTTTCT & CAGTGCGCAGCGTTTGG \\
NaK-ATPase- $\alpha-$ & ACGTTTCAGGATGGGAGTGTT & CCTCTGCAACCGTGCTGAAT \\
subunit & & \\
NaK-ATPase- $\beta-$ & CGCTCACAATTCCACACAACA \\
subunit & & GCACCCCAGGCTTTACACTT \\
\hline
\end{tabular}




\section{Results}

The subtraction efficiency of our study was evaluated by the constitutively expressed gene $\beta$-actin. The amount of $\beta$-actin transcript was hardly detectable in the subtracted library comparing with that in the unsubtracted sample, suggesting that SSH procedure successfully suppressed cDNA constantly expressed in the normal and acute low salinity stressed shrimps.

\subsection{Up-Regulated Genes in Hepatopancreas SSH cDNA Library of Litopenaeus Vannamei}

196 clones were sequenced in hepatopancreas SSH cDNA library. 131 potential transcripts included 21 contigs and 110 singlets were identified by assembling and clustering. 41 with significant homologies to known genes were obtained and categorized according to their putative functions (Table 2), out of which ribosomal protein S15, ribosomal protein S2, ATP/ADP translocase, vesicle-associated membrane protein 2, cytochrome P450 and glutamine synthetase were firstly uncovered in L.vannamei. The genes were functionally clustered into eight biological processes(Figure 1) including protein synthesis and processing, carbohydrate metabolism and energy production, transport, cell growth, apoptosis, cytoskeletal component, cell defense and homeostasis and signal transduction. They accounted for $26.2 \%, 14.3 \%, 16.7 \%, 4.7 \%, 4.7 \%, 2.3 \%, 11.9 \%$ and $7.1 \%$ of the identified genes respectively (Figure 2). The most abundant genes in the subtractive library were related to protein synthesis, indicating protein metabolism in hepatopancreas was rnhanced by acute hypo-osmotic stress. The identification of glucose dehydrogenase and phosphoenolpyruvate carboxykinase also implied the activiation of gluconeogenesis pathway in hepatopancreas. The up-regulation of transport and signal transduction genes suggested the involvement of metabolic pathways and mediated pathways in physiological adaption of L.vannamei to hypoosmotic water.

\section{Genes cluster in hepatopancreas SSH library}

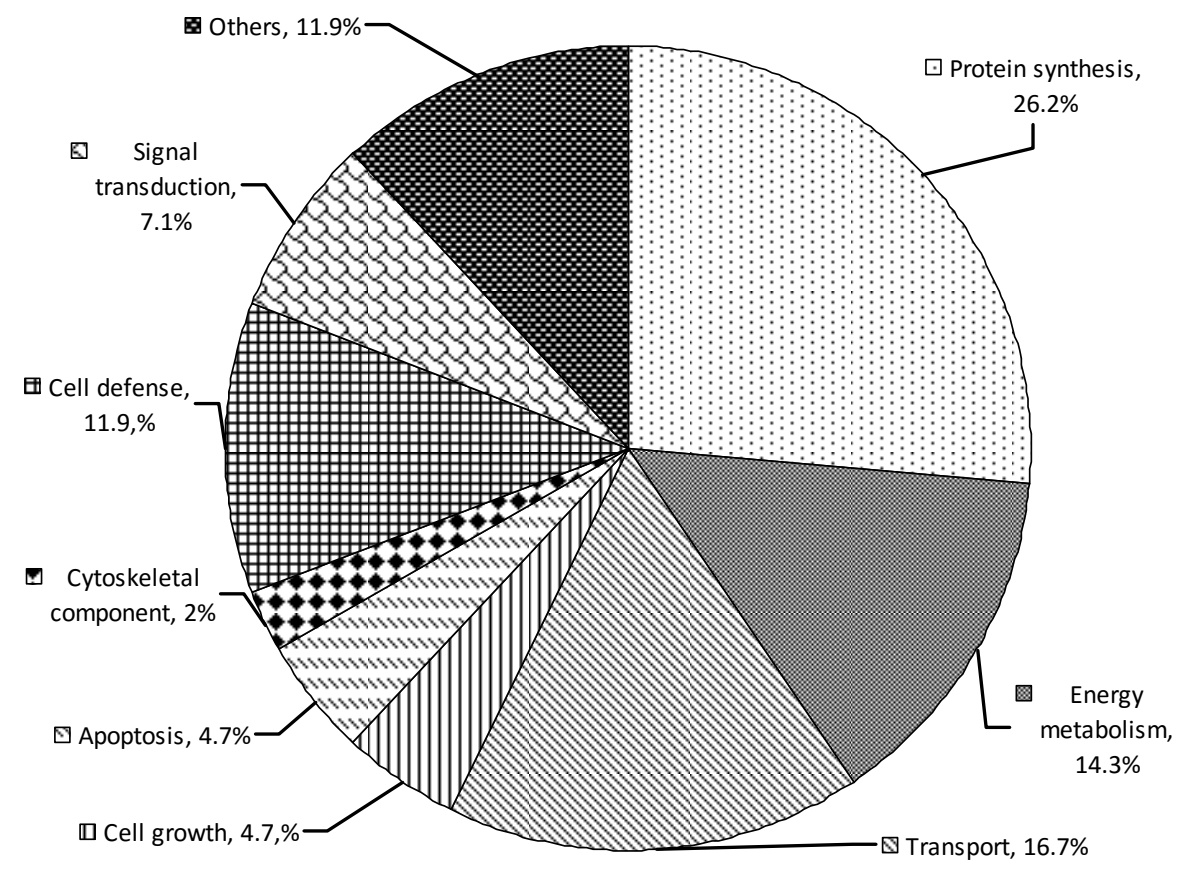

Figure 1. The genes were in hepatopancreas SSH library clustered together according to their predictable functions of protein 


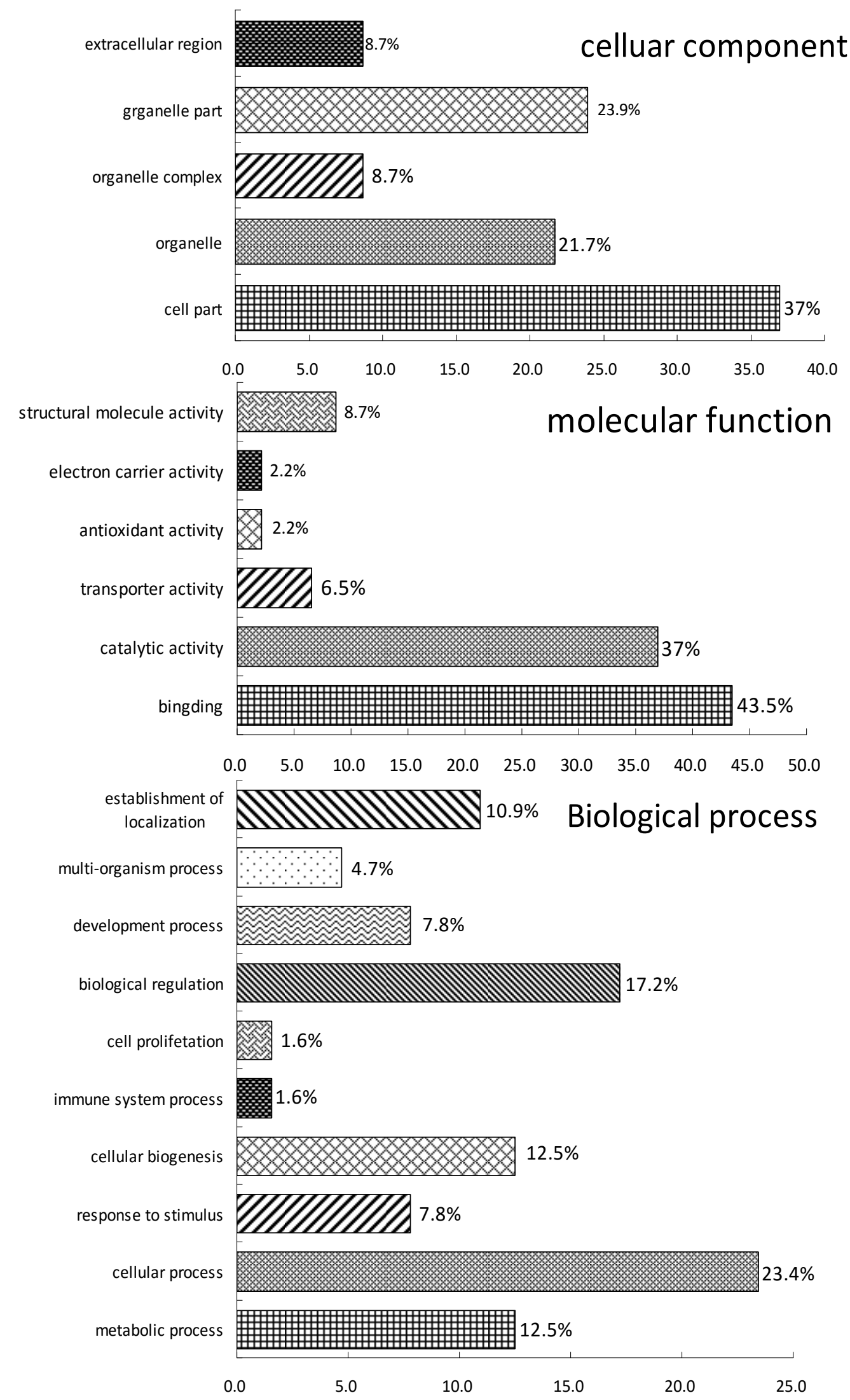

Figure 2. Up-regulation genes were classified according to biological process, molecular function and celluar component 
Table 2. Up-regulated genes indentified in the hepatopancreas of Litopenaeus vannamei after sudden salinity stress by suppression subtractive hybridization ( $\mathrm{SSH})$

\begin{tabular}{|c|c|c|c|c|c|}
\hline Clones & Genes & the closest species & $\begin{array}{l}\text { GeneBank } \\
\text { accession }\end{array}$ & $\begin{array}{l}\text { clones } \\
\text { in } \\
\text { library }\end{array}$ & $\begin{array}{l}\text { E- } \\
\text { value(\%identity) }\end{array}$ \\
\hline \multicolumn{6}{|c|}{ Protein metabolism and processing } \\
\hline contig1 & $\begin{array}{l}\text { eukaryotic translation } \\
\text { initiation factor } 5 \mathrm{~A}\end{array}$ & Penaeus monodon & DQ851145.1 & 1 & $5 e-67 / 96$ \\
\hline contig19 & elongation factor 1 -alpha & $\begin{array}{l}\text { Litopenaeus } \\
\text { vannamei }\end{array}$ & GU136229.1 & 1 & $2 \mathrm{e}-97 / 98$ \\
\hline contig21 & ribosomal protein $\mathrm{S} 15$ & $\begin{array}{l}\text { Spodoptera } \\
\text { frugiperda }\end{array}$ & AF400212.1 & 1 & $9 e-77 / 80$ \\
\hline A82-M13F-A08 & $18 \mathrm{~S}$ ribosomal RNA & $\begin{array}{l}\text { Farfantepenaeus } \\
\text { duorarum }\end{array}$ & FJ943445.1 & 4 & $1 \mathrm{e}-30 / 100 \%$ \\
\hline A57-M13F-H04 & ribosomal protein $\mathrm{S} 2$ & Bombyx mori & NM_001044099.1 & 1 & $1 \mathrm{e}-13 / 76 \%$ \\
\hline A29-M13F-F09 & glutamine synthetase & $\begin{array}{l}\text { Fenneropenaeus } \\
\text { chinensis }\end{array}$ & EU428821.1 & 1 & $1 \mathrm{e}-98 / 92$ \\
\hline F7-M13F_C06 & ribosomal protein L8 & $\begin{array}{l}\text { Litopenaeus } \\
\text { vannamei }\end{array}$ & DQ316258.1 & 1 & $2 \mathrm{e}-32 / 97$ \\
\hline A41-M13F-F05 & $\begin{array}{l}\text { Proteasome subunit alpha } \\
\text { type- } 3\end{array}$ & $\begin{array}{l}\text { Harpegnathos } \\
\text { saltator }\end{array}$ & EFN81786.1 & 1 & $4 e-36 / 69$ \\
\hline \multicolumn{6}{|c|}{ Carbohydrate metabolism and energy production } \\
\hline contig7 & glucose dehydrogenase & Aedes aegypti & XP_001648298.1 & 1 & $4 \mathrm{e}-15 / 57$ \\
\hline contig20 & $\begin{array}{l}\text { phosphoenolpyruvate } \\
\text { carboxykinase (pepck } \\
\text { gene) }\end{array}$ & Penaeus vannamei & AJ250829.1 & 1 & $2 \mathrm{e}-32 / 98$ \\
\hline A46-M13F-E03 & ATP/ADP translocase & $\begin{array}{l}\text { Marsupenaeus } \\
\text { japonicus }\end{array}$ & EF077712.1 & 1 & $1 e-40 / 97$ \\
\hline B3-M13F_C01 & $\begin{array}{l}\text { putative mitochondrial } \\
\text { ATP synthase }\end{array}$ & $\begin{array}{l}\text { Graphocephala } \\
\text { atropunctata }\end{array}$ & ABD98767.1 & 1 & $7 e-10 / 68$ \\
\hline C3-M13F_G02 & $\begin{array}{l}\text { ATP-binding cassette sub- } \\
\text { family A member } 3\end{array}$ & Bos taurus & NP_001107218.1 & 1 & $1 e-34 / 42$ \\
\hline A75-M13F-B07 & $\begin{array}{l}\text { 24-dehydrocholesterol } \\
\text { reductase }\end{array}$ & $\begin{array}{l}\text { Capsaspora } \\
\text { owczarzaki }\end{array}$ & EFW46219.1 & 1 & $1 \mathrm{e}-17 / 41$ \\
\hline \multicolumn{6}{|l|}{ Transport } \\
\hline contig5 & $\begin{array}{l}\text { vesicle-associated } \\
\text { membrane protein } 2\end{array}$ & Xenopus laevis & NP_001080944.1 & 1 & $6 e-19 / 70$ \\
\hline contig11 & hemocyanin & Penaeus monodon & AF431737.1 & 3 & $2 \mathrm{e}-90 / 92$ \\
\hline contig17 & ferritin & Penaeus monodon & ABP68819.1 & 2 & $9 e-13 / 90$ \\
\hline A54-M13F-E04 & $\begin{array}{l}\text { fatty acid binding protein } \\
10\end{array}$ & $\begin{array}{l}\text { Litopenaeus } \\
\text { vannamei }\end{array}$ & DQ398572.1 & 1 & $7 e-69 / 99$ \\
\hline \multicolumn{6}{|l|}{ Cell growth } \\
\hline contig6 & sterol carrier protein $x$-like & $\begin{array}{l}\text { Litopenaeus } \\
\text { vannamei }\end{array}$ & DQ858901.1 & 1 & $0 / 98$ \\
\hline F1-M13F_A05 & Cytochrome P450 & $\begin{array}{l}\text { Harpegnathos } \\
\text { saltator }\end{array}$ & EFN78521.1 & 1 & $7 e-8 / 47$ \\
\hline \multicolumn{6}{|l|}{ Apoptosis } \\
\hline B02_1011006300 & mitochondrion & $\begin{array}{l}\text { Litopenaeus } \\
\text { vannamei }\end{array}$ & DQ534543.1 & 1 & $7 e-145 / 99$ \\
\hline A89-M13F-H08 & $\begin{array}{l}\text { senescence-associated } \\
\text { protein }\end{array}$ & Penaeus vannamei & AF124597.1 & 1 & $3.3 e-28 / 89$ \\
\hline
\end{tabular}




\section{Cytoskeletal component}

contig9

Glutamic acid-rich protein

Plasmodium

P13816.1

$2 \mathrm{e}-5 / 30$

falciparum FC27

\section{Cell defense and homeostasis}

\begin{tabular}{|c|c|c|c|c|c|}
\hline contig 13 & $\begin{array}{l}\text { kazal-type proteinase } \\
\text { inhibitor VANPI-2 }\end{array}$ & $\begin{array}{l}\text { Litopenaeus } \\
\text { vannamei }\end{array}$ & DQ230989.1 & 1 & $2 e-35 / 79$ \\
\hline A25-M13F-B09 & chitinase & $\begin{array}{l}\text { Litopenaeus } \\
\text { vannamei }\end{array}$ & AY576684.1 & 1 & $0 / 88$ \\
\hline A38-M13F-G10 & glutathione S-transferase & $\begin{array}{l}\text { Litopenaeus } \\
\text { vannamei }\end{array}$ & AY573381.1 & 1 & $4 e-30 / 97$ \\
\hline A94-M13F-E09 & MnSOD & $\begin{array}{l}\text { Litopenaeus } \\
\text { vannamei }\end{array}$ & DQ005531.1 & 1 & $2 \mathrm{e}-53 / 100$ \\
\hline G12-M13F_D08 & lectin $\mathrm{A}$ isoform 1 & $\begin{array}{l}\text { Marsupenaeus } \\
\text { japonicus }\end{array}$ & ADG85666.1 & 1 & $7 e-20 / 62$ \\
\hline \multicolumn{6}{|c|}{ Signal transduction } \\
\hline A72-M13F-G06 & $\begin{array}{l}\text { Adapter molecule Crk, } \\
\text { putative }\end{array}$ & $\begin{array}{l}\text { Pediculus } \\
\text { humanus corporis }\end{array}$ & XP_002427598.1 & 1 & $2 e-42 / 82$ \\
\hline A77-M13F-D07 & chitinase precursor & $\begin{array}{l}\text { Litopenaeus } \\
\text { vannamei }\end{array}$ & AF315689.1 & 1 & $8.8 \mathrm{e}-21 / 99$ \\
\hline D5-M13F_C04 & $\begin{array}{l}\text { nuclear progesterone } \\
\text { receptor }\end{array}$ & Penaeus monodon & GU906280.1 & 1 & $0 / 92$ \\
\hline \multicolumn{6}{|l|}{ Others } \\
\hline A78-M13F-E07 & estrogen sulfotransferase & Penaeus vannamei & AF124597.1 & 1 & $3.3 e-28 / 89$ \\
\hline A93-M13F-D09 & hypothetical protein & Daphnia pulex & EFX80592.1 & 1 & $5 e-16 / 55$ \\
\hline C4-M13F_H02 & $\begin{array}{ll}\text { TAR } & \text { RNA-binding } \\
\text { protein } 2 & \end{array}$ & $\begin{array}{l}\text { Fenneropenaeus } \\
\text { chinensis }\end{array}$ & ACG60900.1 & 1 & $1 \mathrm{e}-61 / 100$ \\
\hline G11-M13F_C08 & $\begin{array}{l}\text { tryptophanyl-tRNA } \\
\text { synthetase }\end{array}$ & $\begin{array}{l}\text { Taeniopygia } \\
\text { guttata }\end{array}$ & XP_002200606.1 & 1 & $1 e-50 / 67$ \\
\hline A_2-M13F_B04 & destabilase I & $\begin{array}{l}\text { Litopenaeus } \\
\text { vannamei }\end{array}$ & DQ398564.1 & 1 & $3 e-129 / 98$ \\
\hline
\end{tabular}

Table 3. Different expression genes indentified in gills of $L$ vannamei induced by low-osmotic stress by suppression subtractive hybridization (SSH)

\begin{tabular}{|c|c|c|c|c|}
\hline Oringnal & Genes & Reference Species & $\begin{array}{l}\text { E-Value } \\
\text { (\%identity) }\end{array}$ & $\begin{array}{l}\text { Clones } \\
\text { in library }\end{array}$ \\
\hline \multicolumn{5}{|c|}{ Ion channels and transport proteins } \\
\hline Contig3 & Vesicle transport protein & Mus musculus & $6 e-10 / 54$ & 1 \\
\hline M_T1_E7_G03 & Carbonic anhydrase & Litopenaeus vannamei & $2 e-32 / 98$ & 1 \\
\hline M_T1_F8_A05 & Vesicle-associated membrane protein & Xenopus laevis & $1 e-38 / 53$ & 1 \\
\hline M_T1_H4_G06 & Sodium/potassium -ATPase alpha subunit & Litopenaeus vannamei & $3 e-55 / 93$ & 2 \\
\hline M_T1_H4_G03 & Sodium/potassium- ATPase beta-2 subunit & Litopenaeus vannamei & $1 e-53 / 64$ & 1 \\
\hline M_T1_C9_G01 & Calcium-activated chloride channel regulator 1 & Homo sapiens & $2 \mathrm{e}-11 / 78$ & 1 \\
\hline \multicolumn{5}{|c|}{ Protein synthesis, translation and transcription factor } \\
\hline M_T1_C9_G02 & Mitochondrion 12S & Drosophila melanogaster & $2 \mathrm{e}-135 / 95$ & 1 \\
\hline Contig1 & Single VWC domain protein & Litopenaeus vannamei & $6 e-11 / 45$ & 1 \\
\hline Contig2 & Probable elongation factor 1-delta & Drosophila melanogaster & $8.2 \mathrm{e}-06 / 69$ & 1 \\
\hline M_T1_E5_F03 & Ribosomal protein $\mathrm{L} 7 \mathrm{a}$ & Gallus gallus & $7 e-46 / 72$ & 1 \\
\hline M_T1_E7_G06 & 40S ribosomal protein & Drosophila melanogaster & 2.e-67/99 & 1 \\
\hline Contig7 & Eukaryotic translation initiation factor & Gallus gallus & $3 e-26 / 87$ & 1 \\
\hline Stress resistance & d antioxidant factors & & & \\
\hline
\end{tabular}




\begin{tabular}{lllll}
\hline Contig9 & Major allergen Cr-PII & Periplaneta Americana & $1 \mathrm{e}-19 / 79$ & 1 \\
M_T1_C4_B08 & Beta-lactamase & Escherichia coli & $4.6 \mathrm{e}-34 / 74$ & 1 \\
M_T1_C9_G04 & Ferritin heavy chain & Drosophila melanogaster & $1 \mathrm{e}-46 / 54$ & 2 \\
Contig12 & Thioredoxin 1 (antioxidant protein) & Equus caballus & $2 \mathrm{e}-53 / 79$ & 1 \\
M_T1_E12_D07 & Serine protease & Drosophila melanogaster & $4 \mathrm{e}-12$ & 1 \\
Energy metabolism & & & & \\
M_T1_F8_A08 & NADH dehydrogenase subunit 3 & Drosophila melanogaster & $1 \mathrm{e}-46 / 90$ & 1 \\
M_T1_H4_A06 & NADH ubiquinone oxidoreductase & Drosophila melanogaster & $1 \mathrm{e}-21 / 71$ & 2 \\
M_T1_H2_D09 & Mitochondrial ATP synthaseasubunit precursor & Gallus gallus & $3 \mathrm{e}-85 / 98$ & 1 \\
Contig11 & Arginine kinase & Penaeus monodon & $5 \mathrm{e}-42 / 90$ & 1 \\
Signal receptor and transduction & & & \\
M_T1_H4_F03 & Ornithine decarboxylase antizyme & Mus musculus & $2 \mathrm{e}-20 / 67$ & 1 \\
Contig8 & Ectonucleotide pyrophosphatase & Sus scrofa & $1.1 \mathrm{e}-06 / 47$ & 1 \\
M_T1_E7_F06 & Signal sequence receptor beta-like protein & Danio rerio & $1 \mathrm{e}-38 / 74$ & 1 \\
Cell fibrin and cytoskeletal proteins & & & \\
M_T1_H4_F09 & Actin depolymerizing factor & Drosophila melanogaster & $5 \mathrm{e}-46 / 84$ & 1 \\
Contig5 & Fibrinogen and fibronectin & Mus musculus & $5 \mathrm{e}-9 / 74$ & 1 \\
M_T1_E5_E06 & Beta actin & Litopenaeus vannamei & $2 \mathrm{e}-78 / 100$ & 1 \\
\hline
\end{tabular}

\subsection{Up-Regulated Genes in Gills SSH cDNA Library of Litopenaeus vannamei}

Totally 81 expressed sequence tags (ESTs) were obtained by randomly sequencing from the gill SSH cDNA library, and 52 unigenes, including 15 contigs and 37 singlets, after CP3 online matching were gained by clustering and assembling. The sequence alignment results revealed that 30 of them had significant homology to previously identified Genbank database sequences, while 22 unigenes did not match any sequence in the database and presumably represented unidentified cDNAs. Functionally, the unigenes were classified into 6 clusters (Figure 3), including ion channels and transport proteins (1); protein synthesis, translation and transcription factor (2); stress resistance and antioxidant factors (3); energy metabolism (4); signal receptor and transduction (5); cell fibrin and cytoskeletal proteins (6) with proportion of $23.3 \%, 20.0 \%, 20.0 \%, 16.7 \%, 10.0 \%$ and $10.0 \%$ respectively (Figure 4 ).

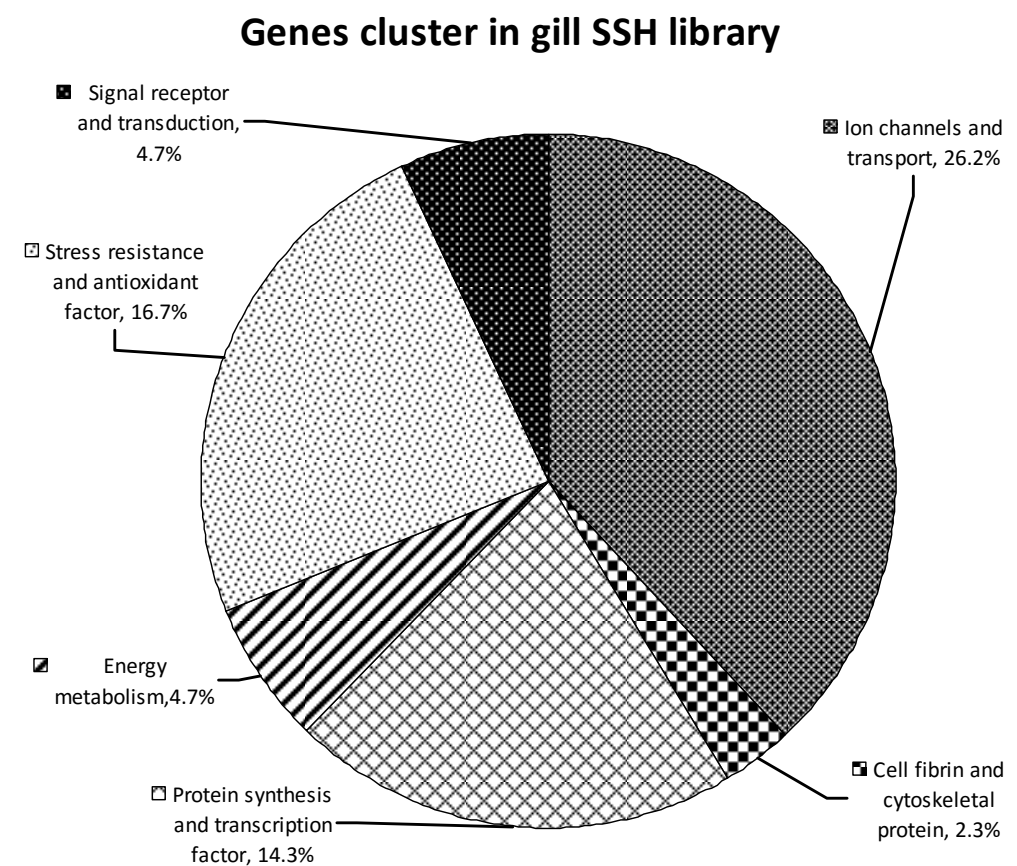

Figure 3. The genes were in hepatopancreas SSH library clustered together according to their predictable functions of protein 


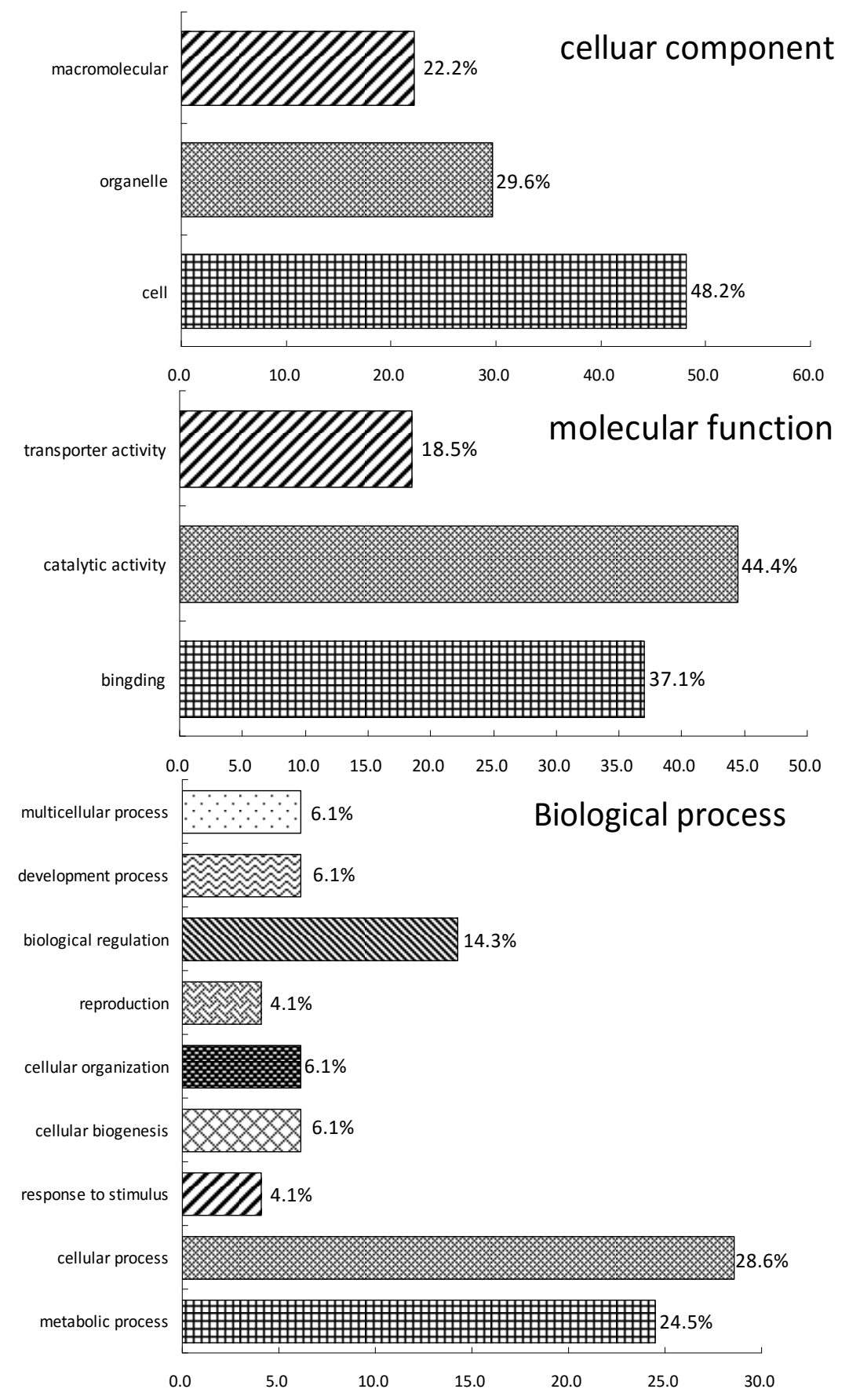

Figure 4. Up-regulated genes were classified according to biological process, molecular function and celluar component

\section{3 qRT-PCRs Check of Up-Regulation of 10 Identified Genes}

Real time qRT-PCRs were conducted to confirm the up-regulation of 10 identified genes including MnSOD, Ferritin, Glutathione, Destabilase I, Glutamine synthetase, Arginine kinase, Carbonic anhydrase, Serine protease, NaK-ATPase- $\alpha$-subunit and NaK-ATPase- $\beta$ - subunit in both hepatopancreas and gill(Figure 5 ). The expression levels of MnSOD, glutathione and glutamine synthetase showed significant increases (2.64-folds, 3.44-folds and 2.16 -folds, respectively) in the hypo-osmotic inducecd hepatopancreas $(P<0.05)$. Significantly elevated expressions of Arginine kinase, Carbonic anhydrase and NaK-ATPase- $\alpha$-subunit were also revealed (3.73-folds, 2.55 -folds and 5.83-folds, respectively) in the acute low-osmotic stressed gill $(P<0.05)$. However, the upregulations of Ferritin, Destabilase I, Serine protease and NaK-ATPase- $\beta$ - subunit were not significant (Figure 5). 


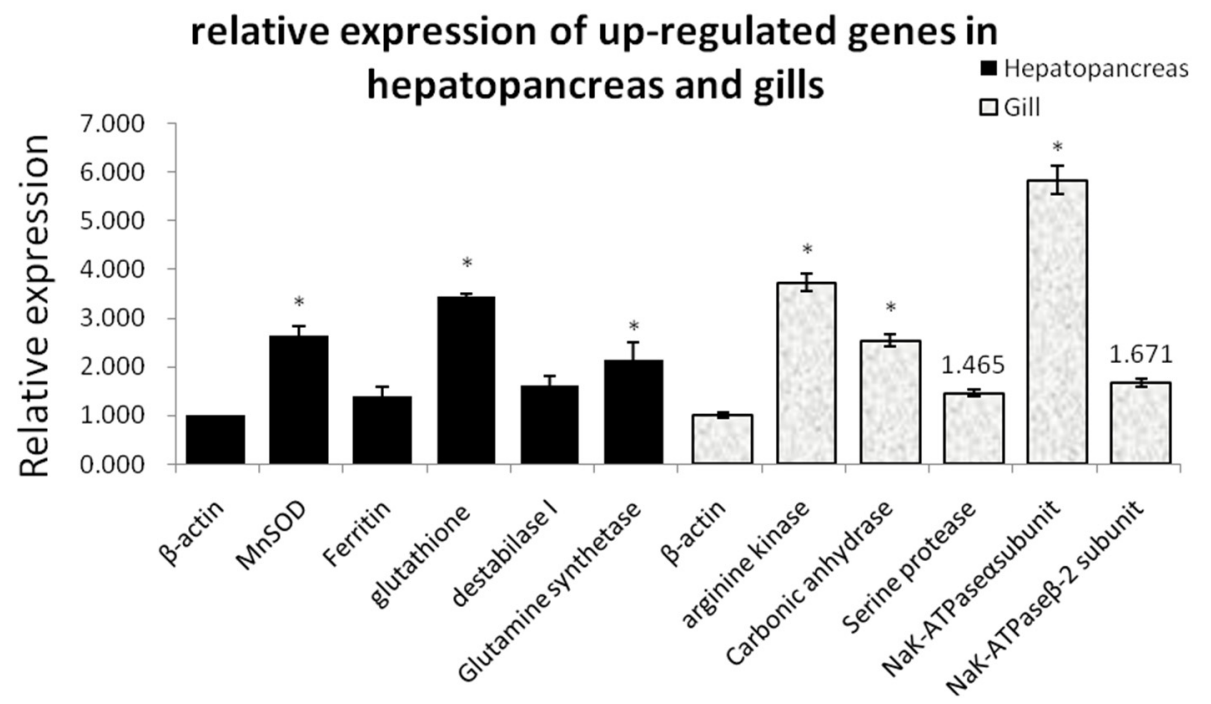

Figure 5. Real time qRT-PCR of the up-regulated genes of hepatopancreas and gills in response to acute low salinity stress

\section{Discussion}

Suppression subtractive hybridization (SSH) is a powerful method for screening abundant transcripts. Preechapho et al., isolated 109 known sequences and identified several reproduction-related transcripts in ovaries of the giant tiger shrimps (P. monodon) using SSH (Preechaphol, Klinbunga, Khamnamtongand, \& Menasveta, 2010). Adisak et al., obtained 185 transcripts and uncovered 8 novel YHV-responsive genes from haemocyte libraries of $P$. monodon induced by yellow head virus after $24 \mathrm{~h}$ and $48 / 72 \mathrm{~h}$ (Prapavorarat, Pongsomboon, \& Tassanakajon, 2010). Four suppression subtractive hybridization (SSH) cDNA libraries were constructed to identify differentially expressed salinity stress responsive genes of black tiger shrimp, Penaeus monodon exposed to low ( 3 ppt) salinity and high (50 ppt) salinity conditions (Shekhar et al., 2013; Shekhar et al., 2014). We also performed uppression subtractive hybridization (SSH) in juvenile L. vannamei exposed to long-term low salinity (2 ppt) for 56 days (Gao et al., 2012). In this study 41 and 30 unigenes were profilled with elevated espression from the hepatopancreas and gill library using SSH respectively. They were clustered into five functional categories in accordance with the blast sequences and functional analysis. We will discuss the functions of these genes clustered in functional groups as follows.

\subsection{Cell Defense, Homeostasis and Immune}

The differential expression of stress-induced and antioxidative-related genes in the hepatopancreas suggested that there might be a novel stress-reponse and remediation patterns. The stress-induced and antioxidative-related genes revealed in the subtractive library included original $\mathrm{Cr}$-pII, the $\beta$-lactamase, ferritin heavy chain, thioredoxin and serine proteases and others. Thioredoxin is a redox regulation protein, which widely presents in prokaryotes and eukaryotes in vivo. In addition, thioredoxin maintains oxidation-reduction balance by reducing the target protein. Thioredoxin, thioredoxin reductase (TrxR), and NADPH compose the thioredoxin system, which catalyzes the reduction of hydrogen peroxide and organic peroxides involved in numerous physiological processes (AispuroHernandez et al., 2008). The reactive oxygen species (ROS) is a major oxidative stress factor in cells. The thioredoxin can reduce the oxidized disulfide bonds to repair oxidative damage in vivo (Garcia-Orozco et al., 2012).The serine protease and homologue may contribute in the innate immunity of the Chinese shrimp (Fenneropenaeus chinensis). Ren et al., reported that the serine protease was activated in normal tissues of the Chinese shrimp (F. chinensis) (Ren et al., 2010). However, the homologue of serine protease was unactivated until stimulated by Vibrio. Serine protease inhibitors (serpins) are widely known to its inhibitory role on proteases involved in the immune responses. Lvserpin 7 transcripts were significantly up-regulated in the early stage upon pathogens infection. $L v \operatorname{serpin} 7$ was implicated in the shrimp immunity via the inhibition of bacterial proteases and proteases involved in prophenoloxidase system (Y. Liu, Hou, Wang, \& Liu, 2015). Despite of previous reports that the innate immunity of L.vannamei was depressed at low salinity (Joseph \& Philip, 2007; C.-C. Li, Yeh, \& Chen, 2010).Five up-regulated immune-related genes were discovered in the hepatopancreas SSH library, including kazal-type proteinase inhibitor vanpin-2, chitinase, glutathione S-transferase, MnSOD and lectin A isoform 1. The up-regulation of these genes indicated that shrimps may keep homeostasis of internal environment 
in hepatopancreas at low salinity. The induction of immune and antioxidant genes under low salinity contributed to the consolidation of the immune defense of $L$. vannamei.

\subsection{Protein Metabolism and Processing}

The transcriptional regulation mechanism of osmoregulation-related genes is modulated by the direction of salinity change and the developmental background of the gill (Zhao et al., 2015). The proportion of protein synthesis and transcription factors was just less than that of ion channels and transport-related genes in the gill forward SSH cDNA library of $L$. vannamei induced by low salinity stress. These genes included mitochondria $12 \mathrm{~s}$, domain protein, elongation factor, ribosomal protein $\mathrm{L} 7 \mathrm{a}, 40 \mathrm{~S}$ ribosomal protein and initial eukaryotic transcription factor. The up-regulation of those genes suggested that the low salinity stress effectively activated the transcription and translation of osmoregulation-related genes and confirmed that the osmoregulation process was a post-translational mechanism (Towle et al., 2001). Researches in Penaeus japonicus showed that the free amino acid (FAA) pool in muscle was directly related to osmoregulationwhile the FAA pool in the hepatopancreas was related to energy expenditure and protein synthesis (Marangos et al., 1989). However, shrimps at $3.0 \mathrm{ppt}$ salinity had significantly higher soluble protein concentration than those at 17.0 and $32.0 \mathrm{ppt}$ in the hepatopancreas (ErChao et al., 2009). We also cloned and identified the Glutamine synthetase of $L$. vannamei from the hepatopancreas forward SSH library. The LvGS can participate in physiological osmotic adaptation to hypo-osmotic water and aid L. vannamei in resisting acute salinity changes via the manipulation of nitrogen metabolism (H.-y. Liu et al., 2012). The number of genes related to protein synthesis and processing was the highest $(26.2 \%)$ in the hepatopancreas SSH library, including eukaryotic translation initiation factor 5A, elongation factor 1-alpha, ribosomal protein $\mathrm{S} 15,18 \mathrm{~S}$ ribosomal RNA, ribosomal protein S2, ribosomal protein L8, and proteasome subunit alpha type-3. These genes whose expression levels were up-regulated possibly accelerated protein synthesis in the hepatopancreas and contributed to the tolerance of low salinity of $L$. vannamei.

\subsection{Carbohydrate Metabolism and Energy Production}

Glucose, as an important source of energy, increased rapidly in the hemolymph of L. vannamei in hypoxia and up to 4.7 and 5.0-fold in response to $1.5 \mathrm{mg} / \mathrm{L}$ Do for $1 \mathrm{~h}$ (Soñanez-Organis et al., 2009). Glucose dehydrogenase and phosphoenolpyruvate carboxykinase are key enzymes involved in gluconeogenesis (Enes, Panserat, Kaushik, \& Oliva-Teles, 2009). These enzymes catalyze macromolecular substances into glucose, thereby maintaining the glucose concentration in hemolymph sufficient for energy expenditure. Numerous genes involving in gluconeogenesis and energy production were uncovered in the SSH library, including glucose dehydrogenase, phosphoenolpyruvate carboxykinase, ATP/ADP translocase, mitochondrial ATP synthase, 24-dehydrocholesterol reductase, and ATP-binding cassette sub-family A member 3. These results indicated the activation of the gluconeogenesis pathway by hypo-osmotic stress and suggested that more energy was consumed for osmoregulation under hypo-osmotic environment. The nicotinamide dehydrogenase (NADH dehydrogenase) and oxidoreductase (NADH ubiquinone oxidoreductase) are involved in the glycolysis and citric acid cycle of cellular respiration. Arginase is a key enzyme involved in ornithine cycle of nitrogen metabolism and catalyzes the hydrolysis of L-arginine to form ornithine and urea. As a part of the urea cycle, arginase is widely expressed and plays a major role gill, hepatopancreas and muscle of crustaceans animals (Chen \& Chen, 1997). The transfer of shrimp and other crustaceans from high to low salinity water results in a diffusive loss of salts from the haemolymph to the medium and, consequently, uptake of water from the medium. As water intake increases in response to low salinity, tissues and cells take up water and increase their volume (Pequeux, 1995). Ornithine decarboxylase is the first rate-limiting enzyme in the dopamine synthesis pathway. It can be activated by the volume increase of tissues and cells induced by low salinity stress (Watts, Yeh, \& Henry, 1996). Biogenic amine synthetase, such as ornithine decarboxylase, is activated to produce biogenic amines, such as dopamine (Sommer \& Mantel, 1988). Dopamine plays an important role in neurotransmission and causes energy metabolism, osmoregulation, and respiratory response modulation. The dopamine can also stimulate $\mathrm{Na}^{+} / \mathrm{K}^{+}$-ATPase activity and $\mathrm{NaCl}$ uptake to maintain the osmolality balance via a cAMP-mediated phosphorylation (Trausch, Forget, \& Devos, 1989).

\subsection{Transport}

In the gill forward SSH cDNA library constructed in this study, transport-related genes made up the largest proportion $(23.3 \%)$, including vesicle transport protein, calcium chloride channel protein stimulated vesicle membrane protein-coupled, $\mathrm{Na}^{+} / \mathrm{K}^{+}$-ATPase $\left(\mathrm{Na}^{+} / \mathrm{K}^{+}\right.$-dependent adenosine triphosphatase enzyme) and carbonic anhydrase enzyme important genes. Moreover, the identification of stimulated calcium chloride channel protein was novel in L. vannamei. The $\mathrm{Na}^{+} / \mathrm{K}^{+}$-dependent adenosine triphosphatase $\left(\mathrm{Na}^{+} / \mathrm{K}^{+}\right.$-ATPase), composed of three subunits $(\alpha, \beta, \gamma)$, is the most important transmembrane protein and predominances in basolateral membrane 
regions of the epithelium (Pequeux, 1995). The $\alpha$-subunit provides the catalytic function of the $\mathrm{Na}^{+} / \mathrm{K}^{+}$- ATPase, binding and hydrolyzing ATP and itself becoming phosphorylated during the transport cycle. The gill SSH library showed that expression of both $\alpha$ and $\beta$ subunits of $\mathrm{Na}^{+} / \mathrm{K}^{+}$-ATPase were simultaneously induced by low salinity stress. During acclimation to dilute seawater, the euryhaline crab Chasmagnathus granulatus $\mathrm{Na}^{+} / \mathrm{K}^{+}$-ATPase $\alpha$ subunit mRNA increased 35-55 folds in posterior gill within the first $24 \mathrm{~h}$. However, the $\mathrm{Na}^{+} / \mathrm{K}^{+}$-ATPase $\beta$ subunit was thought to participate in anchoring the complex in the basolateral membrane (Therien \& Blostein, 2000). Our results were similar to study by Wang et al., who revealed those two genes are sensitive and involved in all different stress responses and are more sensitive to salinity than other stresses may have relationship with the anti-stress mechanism induced by environment stress in shrimp (Wang et al., 2012). The carbonic anhydrase (CA) is a zinc metalloenzymes which involves in many biological processes, including $\mathrm{pH}$ adjustment, ion exchange, $\mathrm{CO}_{2}$ transport, respiration, biosynthesis and so on (Henry, Gehnrich, Weihrauch, \& Towle, 2003). In gill epithelial cells, the $\mathrm{HCO}_{3}{ }^{-}$is provided by carbonic anhydrase which facilitates $\mathrm{CO}_{2}$ excretion, while $\mathrm{NH}_{4}{ }^{+}$substitutes for $\mathrm{K}^{+}$in basal ATPase and for $\mathrm{H}^{+}$in the apical exchange (Morris, 2001). The vesicle transport protein can transport synthesized proteins from endoplasmic reticulun to the apical and basolateral membrane. The up-regulation of vesicle transport protein in the gill forward SSH library indicated that the increasing of protein synthesis activated the vesicle transport protein. The detections of carbonic anhydrase and vesicle transport protein in L. vannamei are also novel. Transport genes showed up-regulation, suggesting metabolic pathways were involved in physiological adaption to hypo-osmotic environment. The organics synthesized and catabolized in the hepatopancreas are transported to other tissues through these proteins, including vesicle-associated membrane protein 2 which directs protein movement out of a cell, within a cell, or between cells. hemocyanin is synthesized in the hepatopancreas binds oxygen and carries oxygen to other tissues (Lehnert \& Johnson, 2002); fatty acid binding protein 10 which is intracellular lipid-binding invovles in absorption, transport and metabolism of lipid (Arena et al., 2011; Venkatachalam, Thisse, Thisse, \& Wright, 2009). The up-regulation of these genes may improve the transport efficiency of organics required bythe maintenance of osmotic balance.

\subsection{Cell Growth, Signal Transduction and Cytoskeletal Component}

The expression of several genes related to cell growth, apoptosis and cytoskeletal component were higher after hypo-osmotic stress, including sterol carrier protein x, cytochrome P450, mitochondrion, senescence-associated protein, glutamic acid-rich protein and glucuronosyl transferases, indicating the acceleration of corporeal cells renewing and its participation in the adaption to low salinity. These results are similar to the report by Shekhar (Shekhar et al., 2013) Numerous genes detected in the SSH library, such as Adapter molecule Crk, putative, chitinase precursor, nuclear progesterone receptor, estrogen sulfotransferase, and destabilase I, are involved in signal transduction and other biological progress. The increased expression of these genes in shrimps with hypoosmotic stress indicated that signal transductions and other biological progresses are involved in osmotic physiological adaption. The phosphodiesterases (PDEs) can hydrolyze and degrade the intracellular second messengers (cAMP, cyclic adenosine monophosphate, or cGMP, cyclic guanosine monophosphate) to end the biochemical effects conducted by those second messengers (Soderling \& Beavo, 2000). In addition, the signal sequence receptors have important functions in numerous physiological processes involved in the recognition of signal sequence, modification of nascent peptide chain and formation of the transport channels (Pequeux, 1995). The cytoskeletal protein and fiber-related genes were found in the gill forward SSH cDNA library. The presence of these genes suggested that transcriptional expression of membrane proteins and cytoskeletal proteins were activated by low salinity stress. This activation resulted in specializations of the gill epithelial membrane structure and ion transport channels to adapt to the changes in the external environment (Towle et al., 2001). The upregulation of signal transduction genes probably suggested the activation of their mediated pathways by hypoosmotic stress. However, the function and progress involved in the adaption to low salinity environment requires further study.

In summary, up-regulated genes in the hepatopancreas and gill of $L$. vannamei involved in physiological adaption to hypo-osmotic environment were screened and identified by SSH. The results indicate that cell defense, homeostasis and immune, protein metabolism and processing, carbohydrate metabolism and energy production, transport, cell growth, apoptosis and cytoskeletal component were activated by hypo-osmotic stress. These data are helpful in providing insight into osmotic physiological adaption to hypo-osmotic environment in the hepatopancreas and gill of L. vannamei. The functions and molecular mechenism of these genes revealed from the hepatopancreas and gills SSH library require further investigation.

\section{Acknowledgments}

This work was supported by the National Natural Science Foundation of China (No. 31272673), the National Basic Research Program of China (2014CB138600), the Special Fund for Agro-scientific Research of Public Interest 
(No. 201003020), Foundation of Guangdong Provincial Key Laboratory of Marine Biotechnology (No. GPKLMB201401), Colleges Pearl River Scholar (GDUPS) (2011) and Project of Enhancing School With Innovation of Guangdong Ocean University (GDOU2015050206, C15390).

\section{References}

Aispuro-Hernandez, E., Garcia-Orozco, K. D., Muhlia-Almazan, A., del-Toro-Sanchez, L., Robles-Sanchez, R. M., Hernandez, J., ... Sotelo-Mundo, R. R. (2008). Shrimp thioredoxin is a potent antioxidant protein. Comparative Biochemistry and Physiology Part C: Toxicology \& Pharmacology, 148(1), 94-99.

Arena, L., Lizama, G., Gaxiola, G., Cuzon, G., Rosas, C., \& Van Wormhoudt, A. (2011). Glutamate dehydrogenase and $\mathrm{Na}+\mathrm{K}+$ ATPase expression and growth response of Litopenaeus vannamei to different salinities and dietary protein levels. Chinese Journal of Oceanology and Limnology, 29(2), 343349.

Bi, K., Huang, H., Gu, W., Wang, J., \& Wang, W. (2008). Phylogenetic analysis of Spiroplasmas from three freshwater crustaceans (Eriocheir sinensis, Procambarus clarkia and Penaeus vannamei) in China. Journal of invertebrate pathology, 99(1), 57-65.

Chen, J.-C., \& Chen, J.-M. (1997). Arginase specific activity and nitrogenous excretion of Penaeus japonicus exposed to elevated ambient ammonia. Marine Ecology Progress Series, 153, 197-202.

Cuzon, G., Lawrence, A., Gaxiola, G., Rosas, C., \& Guillaume, J. (2004). Nutrition of Litopenaeus vannamei reared in tanks or in ponds. Aquaculture, 235(1), 513-551\%@0044-8486.

Diatchenko, L., Lau, Y., Campbell, A. P., Chenchik, A., Moqadam, F., Huang, B., ... Sverdlov, E. D. (1996). Suppression subtractive hybridization: a method for generating differentially regulated or tissue-specific cDNA probes and libraries. Proceedings of the National Academy of Sciences, 93(12), 6025-6030.

Dong, J., Wang, L., Tian, Y., Guo, Y., \& Liu, H. (2011). [hTERT single nucleotide polymorphism is associated with increased risks of hepatocellular carcinoma and tumor metastasis]. Nan fang yi ke da xue xue bao (Journal of Southern Medical University), 31(1), 49-52.

dos Santos Braz, R. d. F., Reis, L. G., Martins, P. C. C., de Sales, M. P., \& Meissner, R. V. (2009). Prevalence of infectious hypodermal and hematopoietic necrosis virus (IHHNV) in Penaeus vannamei cultured in northeastern Brazil. Aquaculture, 288(1), 143-146.

Enes, P., Panserat, S., Kaushik, S., \& Oliva-Teles, A. (2009). Nutritional regulation of hepatic glucose metabolism in fish. Fish Physiology and Biochemistry, 35(3), 519-539.

ErChao, L., LiQiao, C., Ceng, Z., ZeQuan, X., Chen, L., ShiMing, P., \& LiHe, L. (2009). Protein accumulation, amino acid profile and amino transferase activities of the white shrimp, Litopeneaus vannamei, at different salinities. Acta Hydrobiologica Sinica, 33(3), 532-538.

Fiol, D. F., Chan, S. Y., \& Kültz, D. (2006). Identification and pathway analysis of immediate hyperosmotic stress responsive molecular mechanisms in tilapia (Oreochromis mossambicus) gill. Comparative Biochemistry and Physiology Part D: Genomics and Proteomics, 1(3), 344-356.

Franceschini-Vicentini, I. B., Ribeiro, K., Papa, L. P., Marques Junior, J., Vicentini, C. A., \& Valenti, P. M. C. M. (2009). Histoarquitectura del Hepatopáncreas del Camarón de la Amazonia Macrobrachium amazonicum. International Journal of Morphology, 27(1), 121-128.

Gao, W., Tan, B., Mai, K., Chi, S., Liu, H., Dong, X., \& Yang, Q. (2012). Profiling of differentially expressed genes in hepatopancreas of white shrimp (Litopenaeus vannamei) exposed to long-term low salinity stress. Aquaculture, 364, 186-191.

Garcia-Orozco, K. D., Sanchez-Paz, A., Aispuro-Hernandez, E., Gomez-Jimenez, S., Lopez-Zavala, A., AraujoBernal, S., \& Muhlia-Almazan, A. (2012). Gene expression and protein levels of thioredoxin in the gills from the whiteleg shrimp (Litopenaeus vannamei) infected with two different viruses: The WSSV or IHHNV. Fish \& shellfish immunology, 32(6), 1141-1147.

Henry, R. P., Gehnrich, S., Weihrauch, D., \& Towle, D. W. (2003). Salinity-mediated carbonic anhydrase induction in the gills of the euryhaline green crab, Carcinus maenas. Comparative Biochemistry and Physiology Part A: Molecular \& Integrative Physiology, 136(2), 243-258.

James, R., Thampuran, N., Lalitha, K., Rajan, L. A., \& Joseph, T. C. (2010). Differential gene expression profile of the hepatopancreas of white spot syndrome virus infected Fenneropenaeus indicus by suppression subtractive hybridization. Fish \& shellfish immunology, 29(5), 884-889.

Jasmani, S., Jayasankar, V., Shinji, J., \& Wilder, M. N. (2010). Carbonic anhydrase and Na/K-ATPase activities during the molt cycle of low salinity-reared white shrimp Litopenaeus vannamei. Fisheries Science, 76(2), 219-225. 
Jayasundara, N., Spanings-Pierrot, C., \& Towle, D. (2004). Quantitative analysis of hsp 70 mRNA expression under salinity stress in the euryhaline shore crab Pachygrapsus marmoratus. Paper presented at the Integrative and Comparative Biology.

Joseph, A., \& Philip, R. (2007). Acute salinity stress alters the haemolymph metabolic profile of Penaeus monodon and reduces immunocompetence to white spot syndrome virus infection. Aquaculture, 272(1), 87-97.

Lehnert, S. A., \& Johnson, S. E. (2002). Expression of hemocyanin and digestive enzyme messenger RNAs in the hepatopancreas of the Black Tiger Shrimp Penaeus monodon. Comparative Biochemistry and Physiology Part B: Biochemistry and Molecular Biology, 133(2), 163-171.

Li, C.-C., Yeh, S.-T., \& Chen, J.-C. (2010). Innate immunity of the white shrimp Litopenaeus vannamei weakened by the combination of a Vibrio alginolyticus injection and low-salinity stress. Fish \& shellfish immunology, 28(1), 121-127.

Li, E., Chen, L., Zeng, C., Yu, N., Xiong, Z., Chen, X., \& Qin, J. G. (2008). Comparison of digestive and antioxidant enzymes activities, haemolymph oxyhemocyanin contents and hepatopancreas histology of white shrimp, Litopenaeus vannamei, at various salinities. Aquaculture, 274(1), 80-86.

Liu, H.-y., Sun, W.-w., Tan, B.-p., Chi, S.-y., Dong, X.-h., \& Yang, Q.-h. (2012). Molecular cloning and expression of hepatopancreas glutamine synthetase in the Pacific white shrimp, Litopenaeus vannamei, induced by acute hypo-osmotic stress. Aquaculture, 362, 80-87.

Liu, Y., Hou, F., Wang, X., \& Liu, X. (2015). Recombinant expression and characterization of a serine protease inhibitor (Lvserpin7) from the Pacific white shrimp, Litopenaeus vannamei. Fish \& shellfish immunology, 42(2), 256-263.

Lovett, D. L., Verzi, M. P., Burgents, J. E., Tanner, C. A., Glomski, K., Lee, J. J., \& Towle, D. W. (2006). Expression profiles of $\mathrm{Na}+, \mathrm{K}+$-ATPase during acute and chronic hypo-osmotic stress in the blue crab Callinectes sapidus. The Biological Bulletin, 211(1), 58-65.

Luquet, C. M., Weihrauch, D., Senek, M., \& Towle, D. W. (2005). Induction of branchial ion transporter mRNA expression during acclimation to salinity change in the euryhaline crab Chasmagnathus granulatus. Journal of experimental biology, 208(19), 3627-3636.

Marangos, C., Brogren, C.-H., Alliot, E., \& Ceccaldi, H.-J. (1989). The influence of water salinity on the free amino acid concentration in muscle and hepatopancreas of adult shrimps, Penaeus japonicus. Biochemical Systematics and Ecology, 17(7), 589-594.

Morris, S. (2001). Neuroendocrine regulation of osmoregulation and the evolution of air-breathing in decapod crustaceans. Journal of Experimental Biology, 204(5), 979-989.

Pan, D., He, N., Yang, Z., Liu, H., \& Xu, X. (2005). Differential gene expression profile in hepatopancreas of WSSV-resistant shrimp (Penaeus japonicus) by suppression subtractive hybridization. Developmental \& Comparative Immunology, 29(2), 103-112.

Pan, L.-Q., Zhang, L.-J., \& Liu, H.-Y. (2007). Effects of salinity and pH on ion-transport enzyme activities, survival and growth of Litopenaeus vannamei postlarvae. Aquaculture, 273(4), 711-720.

Pequeux, A. (1995). Osmotic regulation in crustaceans. Journal of Crustacean Biology, 1-60.

Pillai, B. R., \& Diwan, A. (2002). Effects of acute salinity stress on oxygen consumption and ammonia excretion rates of the marine shrimp Metapenaeus monoceros. Journal of Crustacean Biology, 22(1), 45-52.

Prapavorarat, A., Pongsomboon, S., \& Tassanakajon, A. (2010). Identification of genes expressed in response to yellow head virus infection in the black tiger shrimp, Penaeus monodon, by suppression subtractive hybridization. Developmental \& Comparative Immunology, 34(6), 611-617.

Preechaphol, R., Klinbunga, S., Khamnamtongand, B., \& Menasveta, P. (2010). Isolation and characterization of genes functionally involved in ovarian development of the giant tiger shrimp Penaeus monodon by suppression subtractive hybridization (SSH). Genetics and molecular biology, 33(4), 676-685.

Ren, Q., Zhang, X.-W., Sun, Y.-D., Sun, S.-S., Zhou, J., Wang, Z.-H., . . W Wang, J.-X. (2010). Two cysteine proteinases respond to bacterial and WSSV challenge in Chinese white shrimp Fenneropenaeus chinensis. Fish \& shellfish immunology, 29(4), 551-556.

Shekhar, M., Kiruthika, J., \& Ponniah, A. (2013). Identification and expression analysis of differentially expressed genes from shrimp (Penaeus monodon) in response to low salinity stress. Fish \& shellfish immunology, 35(6), 1957-1968.

Shekhar, M., Kiruthika, J., Rajesh, S., \& Ponniah, A. (2014). High salinity induced expression profiling of differentially expressed genes in shrimp (Penaeus monodon). Molecular biology reports, 41(9), 62756289. 
Silvia, G.-J., Antonio, U.-R. A., Francisco, V.-O., \& Georgina, H.-W. (2004). Ammonia efflux rates and free amino acid levels in Litopenaeus vannamei postlarvae during sudden salinity changes. Aquaculture, 233(1), 573-581.

Soñanez-Organis, J. G., Peregrino-Uriarte, A. B., Gómez-Jiménez, S., López-Zavala, A., Forman, H. J., \& YepizPlascencia, G. (2009). Molecular characterization of hypoxia inducible factor-1 (HIF-1) from the white shrimp Litopenaeus vannamei and tissue-specific expression under hypoxia. Comparative Biochemistry and Physiology Part C: Toxicology \& Pharmacology, 150(3), 395-405.

Soderling, S. H., \& Beavo, J. A. (2000). Regulation of cAMP and cGMP signaling: new phosphodiesterases and new functions. Current opinion in cell biology, 12(2), 174-179.

Sommer, M. J., \& Mantel, L. H. (1988). Effect of dopamine, cyclic AMP, and pericardial organs on sodium uptake and $\mathrm{Na} / \mathrm{K}$ - ATPase activity in gills of the green crab Carcinus maenas (L). Journal of experimental zoology, 248(3), 272-277.

Therien, A. G., \& Blostein, R. (2000). Mechanisms of sodium pump regulation. American Journal of PhysiologyCell Physiology, 279(3), C541-C566.

Thongsawad, S., Baumann, M., Graubaum, D., Hildebrandt, G., Khattiya, R., Zessin, K.-H., \& Möh, K. (2007). Erhebungen über das Vorkommen von Noroviren bei Pacific White Shrimps [Litopenaeus vannamei) in Thailandbr> Research about the prevalence ofnorovirus in Pacific White Shrimps (Litopeneaus vannamei) in Thailand.

Tiu, S. H., He, J.-G., \& Chan, S.-M. (2007). The LvCHH-ITP gene of the shrimp (Litopenaeus vannamei) produces a widely expressed putative ion transport peptide (LvITP) for osmo-regulation. Gene, 396(2), 226-235.

Towle, D. W., Paulsen, R. S., Weihrauch, D., Kordylewski, M., Salvador, C., Lignot, J.-H., \& Spanings-Pierrot, C. (2001). Na++ K+-ATPase in gills of the blue crab Callinectes sapidus: cDNA sequencing and salinityrelated expression of $\alpha$-subunit mRNA and protein. Journal of Experimental Biology, 204(22), 40054012.

Trausch, G., Forget, M.-C., \& Devos, P. (1989). Biomines-stimulated phosphorylation and (Na+, K+-ATPase in the gills of the chinese crab, Eriocheir sinensis. Comparative Biochemistry and Physiology Part B: Comparative Biochemistry, 94(3), 487-492.

Venkatachalam, A. B., Thisse, C., Thisse, B., \& Wright, J. M. (2009). Differential tissue - specific distribution of transcripts for the duplicated fatty acid - binding protein 10 (fabp10) genes in embryos, larvae and adult zebrafish (Danio rerio). FEBS journal, 276(22), 6787-6797.

Wang, L., Wang, W.-N., Liu, Y., Cai, D.-X., Li, J.-Z., \& Wang, A.-L. (2012). Two types of ATPases from the Pacific white shrimp, Litopenaeus vannamei in response to environmental stress. Molecular biology reports, 39(6), 6427-6438.

Watts, S. A., Yeh, E. W., \& Henry, R. P. (1996). Hypoosmotic stimulation of ornithine decarboxylase activity in the brine shrimp Artemia franciscana. Journal of Experimental Zoology, 274(1), 15-22.

Zhang, P., Zhang, X., Li, J., \& Gao, T. (2009). Effect of salinity on survival, growth, oxygen consumption and ammonia - N excretion of juvenile whiteleg shrimp, Litopenaeus vannamei. Aquaculture research, 40(12), 1419-1427.

Zhao, Q., Pan, L., Ren, Q., \& Hu, D. (2015). Digital gene expression analysis in hemocytes of the white shrimp Litopenaeus vannamei in response to low salinity stress. Fish \& shellfish immunology, 42(2), 400-407.

\section{Copyrights}

Copyright for this article is retained by the author(s), with first publication rights granted to the journal.

This is an open-access article distributed under the terms and conditions of the Creative Commons Attribution license (http://creativecommons.org/licenses/by/3.0/). 